\title{
Corporate Governance and Sustainable Development in Nigeria: A Study of Oil Companies in the Niger Delta Region
}

\author{
Leyira Christian Micah $^{1} \&$ Asian A Umobong ${ }^{1}$ \\ ${ }^{1}$ Department of Accounting, University of Port Harcourt, Nigeria \\ Correspondence: Leyira Christian Micah, Department of Accounting, University of Port Harcourt, Nigeria. Tel: \\ 234-803-354-2244. E-mail: leyimic@yahoo.com
}

Received: Jaunary 25, 2013

Accepted: February 27, 2013

Online Published: March 26, 2013

doi:10.5539/ijbm.v8n7p127

URL: http://dx.doi.org/10.5539/ijbm.v8n7p127

\begin{abstract}
This research work investigates the relationship between corporate governance structures and sustainable development of oil companies in the Niger Delta Region of Nigeria. The research is based on a survey carried and on a representative sample of five major oil prospecting firms in the region. Questionnaires were used based on 5 point likert scale. Data were analyzed using SPSS version 17.0. The result shows that, good corporate governance will enable companies place priority to technological innovation that will not impair the environment and provide basic amenities and welfare to the communities of operation. It is recommended that government should provide stable investment rules and regulatory incentives for companies to foster sustainable development in the Niger Delta.
\end{abstract}

Keywords: corporate governance, sustainable development, exploitation

\section{Introduction}

Sustainable development is the steady level of development that focuses on the needed infrastructure that changes lives for the better with substantial reduction in ecological or environmental damages. The issue of sustainable development presents some disturbing and contrasting features in various countries. Due to the high level of technical advancement in developed countries, the primary concern is how organizations will go on expanding and sustaining growth and in the process ensure continuous stimulation of consumption through provision of high technology and better quality products and high level of welfare. In the developing countries like Nigeria, the burning question largely revolves around how to stimulate growth.

However, as rightly observed by WCED (2004), little attempt has been made since, for an agreement through which this knowledge would be transferred to developing countries. This is very worrisome to strategic corporate governance. Fundamentally, many industry watchers have expressed serious concern that oil companies in the Niger Delta have not been achieving corporate goals meaningfully, as there is exploitation of natural resources, and the imperative to balance economic wealth and ecological protections. Managers must be capable of cultivating conceptual thinking, setting achievable goals and objectives to be met as well as prioritizing activities and arriving at appropriate decisions. It is expected that corporate managers are to provide a stable framework where policies are formulated for the purpose of achieving organizational goals. Such policies should operate within the principles of fairness between the business and various stakeholders.

\subsection{Statement of the Problem}

Oil exploration is an energy intensive activity with severe implication on people and the environment. The environmental stakeholders are under moral and legal obligation to protect and enhance the natural environment. However, environmental policies and regulations are not lacking but are rarely enforced especially in Nigeria (Micah, Ironkwe \& Adebayo, 2012).

In Nigeria several legislations such as constitution of the federal republic of Nigeria, EIA act 1992, EGASPIN, 2002 , etcetera have been enacted to curb environmental damage, yet nobody takes responsibility and nobody is punished.

It is also observed with dismay that some of the regulators have become necessary operators in the oil industry, thus, the regulation on environmental matters do not have much impact. This has led to compromise between 
what ought to be done and what is done. Enforceable legislation is central to ensuring that the environment is not degraded. Activities of oil exploration and exploitation have made lives and livelihood meaningless. This state of affair is not in the interest of any nation. Our major concern is that companies have the responsibility through policies to make the environment friendly and habitable.

Sustainable development is expected to be a priority issue and a major consideration by board members before profit consideration.

The purpose of this study is therefore to examine the relationship between corporate governance (top management polices) and sustainable development.

The specific objectives include:

(i) To determine whether corporate governance (top management policies) has significant relationship with technological innovation.

(ii) To find out whether corporate governance (top management policies) has significant relationship with welfare.

\subsection{Hypothesis}

$\mathrm{Ho}_{1}$ : Corporate governance has no significant relationship with technological innovation.

$\mathrm{Ho}_{2}$ : There is no significant relationship between corporate governance and high level of welfare.

\subsection{Scope of the Study}

The scope of this work covers the five major oil companies in the Niger Delta region in Nigeria. In addition, thestudy is limited to data/information with respect to corporate governance and sustainable development in the regional operational head offices of the five major oil companies located in the Niger Delta.

\section{Review of Related Literature}

\subsection{The Nature of Development}

Development generally refers to "the state of a particular society and the processed change experienced within it; It is also generally regarded as involving some sorts of progress in four principal directions, namely technology, welfare, economic growth and modernization" (Small and witherick, 1986). This must however involve the whole of society and embracing cultural and social as well as economic and technological change. Where these characteristics can be progressively sustainable a state of sustainable development would prevail.

\subsection{Technological Issues}

The dominant obsession of Nigeria has remained industrialization and sustainable development. One concept that had remained relevant to commentators of sustainable development is technology. This has come about as a result of the belief among developing countries that technologicalinnovation is a veritable strategy for sustainable development and consequently economic development. This development includes the development of technology through corporate governance. A well-managed Company will respond to social issues, placing higher priority on technology that will not impair the environment in the company's operation. If development will be meaningful, technology will be in place. That is, in order to achieve the goals of sustainable development companies have to introduce and apply environmentally friendly technologies. According to Natufe (2001), the challenge for policy in this regard is to combine a favorable context for research, development and deployment with market based evaluation and implementation.

One way to facilitate the absorption of technological innovation and the eventual technology transfer is the attraction and acquisition of the type of technology whose sophistication is friendly to the environment. Functional managers should reject the "Silo" attitude or inept behavior toward risks. Risk assessment and internal control are suggested as responses to the technology challenge.

\subsection{Oil Exploration, Exploitation and Welfare in the Niger Delta}

Despite the fact that Niger delta region is endowed with oil minerals, It is observed that Niger Delta region has low life expectances, low level of literacy andeducational attainment, poor health statistics, little capital stock and low saving rate, an economic structure heavily skewed towards subsistence living. From these stylize, but mostly valid generalizations, poverty and low productivity are predominant because of low level of capital stock per worker resulting from the inability of poor people to save and there is a "vicious" circle (Guardian, Monday, Oct 2, 2006). Eyinla and Ekpo (2006) also attributed some of the causes of oil spillage in oil producing areas in Nigeria to blow outs, corrosion, equipment failure and operational error. 
Corroborating Eyinla et al, UNEP report shows that $50 \%$ of oil spills in Nigeria is due to corrosion of oil infrastructure, engineering drills, inability to effectively control oil wells, failure of machines. The most insensitive nature of this oil companies' operation is flaring of gas in the middle of the villages. This action has affected wild life and the ecosystem. There are severe discomforts and misery particularly when the wind carries fumes, heat and combustion gases to communities.

Many developed nations including United States have very strict regulations with respect to offshore drilling, but Nigeria does not. Committing any error in US waters attract severe penalties. But managers and chief executives of oil companies in the Niger delta operate with reckless abandon. It is inconsequential if the companies' reputation is daunted due to spillage provided there is increase in the profit margins.

The Delta State Governor, Dr. Uduaghan, stressed the point that oil does not last forever. "If the demand for resource control has remained trenchant, it is simply because our people have for long lived with the stark evidence of a mindless exploitation of the oil resources in their land. They have lived with the despoliation and degradation of their environments without concomitant benefits". He noted that the peaceful nature of the people" is taken for granted, adding that oil will not last forever. (The Nation, August 27, 2012)

\subsection{Corporate Governance and Welfare}

Oil firms in the Niger Delta region suffer distress from a number of factors; including inhibitive policy environment, managerial problems and economic downtown. Some of these factors relate to the corporate governance framework. It is universally acknowledged that quality of management (corporate governance) make a significant difference between a sound and unsound firms. Poor management is therefore seen as the most important cause of business failing on their responsibility. One very significant characteristic of management is the negative attitude of managers of oil firms in the Niger Delta region. A common type of management identified in the oil companies includesTechnical Mismanagement. Technical mismanagement involves inadequate policy guidelines and lack of standard practices. The management functions squarely rest on legitimate decision makers. These decision or policy makers constitute the governing board where policies are taken as it affects the operation and achieving of set objectives in dynamic environment. Organization structure provides the administrative framework for the pattern of governance that will engender social and economic transformation. There should be focal areas of development, environment, infrastructure development and human capacity development.

The fact remains that the people of Niger delta struggle to make ends meet, whose livelihood continue to be significantly altered by oil spills. Rittson and Marsden (2003) suggest that sustainable competitive advantage is achieved through the acquisition of unique resources and the development of unique skills. Opportunities exist for business to invent new technologies to improve their operations in a way that addresses the environmental consequences of their activities.

\subsection{Niger Delta Development Commission (NDDC) and Sustainable Development}

The South-South economic submit organized a seminar on a broad theme "Integrating the South-South for sustainabledevelopment" noted the progress made on the legal framework for the cooperation of the Niger Delta States (Oyster 2012). The summit adopted among others the following recommendations.

- To developthe governance structure and the legal environment that will encourage other development partners to invest in the region.

- To review the current policies on power and gas so that states could build their individual plant to foster economic development.

- To encourage research and development and use of technology to promote the desired accelerated development of the region.

- The immediate adoption of mitigation and adoption measures in climate change, bio-diversity conservation, and-use planning and infrastructure designs by Niger Delta States and key into investment opportunities.

\subsection{Consequences of Weak Governance Structure}

Several plans made in the past to improve the lives of the people of the Niger Delta are futile due toendemic mismanagement and corporate corruption. Wealth generated from oil did not benefit the people. Failure to invest in basic infrastructure such as roads and electricity has hampered development. Very few minorities grew richer and vast majority swarm into abject poverty. Good governance requires the capacity to reform. Economies at the fore front of technological development need different kinds of policies;so also governance 
challenges are different than economies seeking to industrialize, which requires improvement through innovations. State officials manipulate and monopolize oil policy and revenue to the exclusion of others; especially the oil bearing communities, frequent frictions and disagreement become inevitable. Oil companies would enter into agreement with militant groups and youths who control areas of the host community that have huge oil deposits. The attitudes of the companies clearly demonstrate power of repression (Eyinla \& Ekpo, 2006).

\section{Methodology}

The required primary data was collected by providing a structured survey of 150 well designed questionnaires sent to five major oil companies in the Niger Delta Region. Access to this company staff was possible through some of our students undergoing post graduate programme that are staff of these companies.

Questionnaire was designed based on other published journal articles. Out of 150 questionnaires delivered, 90 responses were received for the final data analysis, representing a final response rate of $60 \%$. Amongst the respondents were General Managers, Managing Directors/CEO, Accountants and managers (middle level managers), engineers and others without job designations. The companies include: Shell, Agip, Mobil, Texaco, Chevron.

\subsection{Model Specification}

Model 1:

$$
\begin{array}{cc}
T I=f(C G) & \text { (implicit form) } \\
T I=\beta_{0}+\beta_{I} C G+U & \text { (explicit form) }
\end{array}
$$

Model 2:

$$
\begin{array}{cc}
W=f(C G) & \text { (implicit form) } \\
W=\Omega_{0}+\Omega_{l} C G+U_{2} & \text { (explicit form) }
\end{array}
$$

Where:

$\mathrm{CG}=$ Corporate Governance;

$\mathrm{TI}=$ Technological Innovation;

$\mathrm{W}=$ Welfare;

$\beta_{0}, \Omega_{0}=$ Intercept;

$\beta_{1}, \Omega_{1}=$ Regression coefficient;

a'priori expectation;

$\beta_{1}>0, \Omega_{1}>0$

\begin{tabular}{|c|c|c|c|c|c|c|c|c|c|}
\hline Variables & Coef. & $\mathrm{t}$-cal & $\mathrm{t}-\mathrm{tab}_{(0.05,89)}$ & sig. $t$ & $\mathrm{R}$ & $\mathrm{R}^{2}$ & F-cal & $\mathrm{F}-\operatorname{tab}_{(0.05,1,88)}$ & Sigf \\
\hline Constant & 0.621 & 6.726 & 1.96 & 0.000 & 0.889 & 0.790 & 1848 & 3.92 & 0.000 \\
\hline CG & 1.171 & 42.998 & & 0.000 & & & & & \\
\hline
\end{tabular}

\section{Results and Analysis}

Table 1. Summary of simple regression analysis result showing the relationship between corporate governance and technological innovation

Dependent Variable: Technological Innovation (TI).

Table 1 above is the summary of regression analysis result on the relationship betweenCorporate Governance and Technological Innovation. The table revealed that the Pearson's correlation coefficient (r) is 0.889 . This value is high indicating that a strong relationship exists betweenCorporate Governance and Technological Innovation. The positive sign of the coefficient is an indication that a direct relationship exists between Corporate Governance and Technological innovation. That is, a better Corporate Governance is accompanied with increase in Technological Innovation. The Coefficient of determination $\left(\mathrm{R}^{2}\right)=0.790$. This shows that $79 \%$ variation in Technological Innovation is explained by variations in Corporate Governance, The remaining $21 \%$ is explained by other variables not included in the model. Since the explanation is greater than $50 \%$, the researcher concludes that the model has a good fit. 
The F-test conducted showed a good model utility (F-calculated $=1848>$ F-tabulated $(0.05,2,27)=3.92$, the corresponding significant value (PV) of $0.000<0.05$ level of significance).

\section{$\mathrm{HO}_{1}$ “Corporate Governance has no significant relationship with Technological Innovation”}

The test of significance thatCorporate Governance do no significantly relate with Technological Innovation showst-calculated $=42.998>$ t-tabulated ${ }_{(0.05,29)}=1.96, \mathrm{PV}=0.000<0.05$ level of significance. The researcher therefore rejects the null hypothesis and concludes that Corporate Governance has significant relationship with Technological Innovation in the studied area.

Table 2. Summary of simple regression analysis result showing the effects corporate governance on welfare

\begin{tabular}{cccccccccc}
\hline Variables & Coef. & $\mathrm{t}$-cal & $\mathrm{t}_{\text {-tab }}(0.05,89)$ & sig. $\mathrm{t}$ & $\mathrm{R}$ & $\mathrm{R}^{2}$ & $\mathrm{~F}$-cal & F-tab $(0.05,1,88)$ & Sigf \\
\hline Constant & 2.925 & 29.46 & \multirow{2}{*}{1.96} & 0.000 & \multirow{2}{*}{0.875} & 0.762 & 286 & 3.92 & 0.000 \\
CG & 0.493 & 16.93 & & 0.000 & & & & & \\
\hline
\end{tabular}

Dependent Variable: Welfare (W).

Table 2 above shows the Summary of Regression Analysis result on the relationship between Corporate Governance andWelfare. The table specifically indicates that the Pearson's correlation coefficient (r) is 0.875 . This value is high and positively signed indicating that a strong direct relationship exists betweenCorporate Governance and Welfare. The positive sign of the coefficient is an indication that a better Corporate Governance is accompanied with increased Welfare. The Coefficient of determination $\left(\mathrm{R}^{2}\right)=0.762$. This shows that $76.2 \%$ variation in Technological Innovation is explained by variations in Corporate Governance, The remaining $23.8 \%$ is explained by other variables not included in the model. Since the explanation is greater than $50 \%$, the researcher concludes that the model has a good fit.

The F-test conducted showed a good model utility $\left(\mathrm{F}\right.$-calculated $=286>\mathrm{F}$-tabulated $\mathrm{d}_{(0.05,2,27)}=3.92$, the corresponding significant value (PV) of $0.000<0.05$ level of significance).

\section{$\mathrm{HO}_{2}$ "Corporate Governance has no significant relationship with Welfare}

The test of significanceshowst-calculated $=16.93>$ t-tabulated ${ }_{(0.05,29)}=1.96, P V=0.000<0.05$ level of significance. The researcher therefore rejects the null hypothesis and concludes that Corporate Governance has significant relationship withWelfare.

\section{Discussion and Conclusion}

The purpose of this research was to examine the relationship between corporate governance and sustainable development. The findings of this research have several theoretical and practical implications, which are discussed below.

A significant relationship was found between corporate governance and Technological Innovation. This finding aligns with the literature which suggests that a well-managed company Corporate Governance will respond to social issues, placing higher priority on technology that will not impair the environment in the companies operation (Natufe 2001). Managers of business firms should invest in technology and system that are friendly to the environment because they provide real economic value to the business. The business perspective calls attention to the organizational and managerial nature of technological change. A modern technology represents an organizational and management solution to a challenge or problem posed by the environment (Rao 2005). Strong senior management support for technology investment and change enable the firm to increase its revenue or decrease its costs by helping managers make decisions that improves the execution of business processes. Modern technology reduces the problem of environmental degradation, thus enhancing organizational performance, reduction in compensation arising from spillage and ultimately, increases in firm profitability.

The second hypothesis also revealed that good corporate governance has a significant and positive relationship with welfare. It is a well-known fact that over 80 percent of Niger Deltans were farmers and fisher men before oil exploration and exploitation changed the equation. Now, most of these hitherto self-reliant people have been rendered jobless by the activities of oil companies. No thanks to many years of ceaseless gas flaring, combined with incessant oil spillages which rendered the land and rivers unproductive. A good corporate governance mechanism helps ensure that the management properly operates within internationally accepted best practices that will balance the interest of the organization and the other stakeholders. The role of corporate Governance mechanisms in financial reporting is to ensure compliance with generally Accepted Accounting Principles (GAAP) and to maintain credibility. Recently, Corporate Governance has been the focus of evolving regulations 
and prior studies whose attributes relate to the organization and functions of the board in general and its audit committee in particular (Lin and Hwang, 2010). The challenges of pollution notwithstanding, providing sustainable means of livelihoods for the teaming army of the unemployed in the Niger Delta, calls for a reform in international best practices in corporate governance, given the continued reliance and dependence on the development of rules in the governance policy arena. Through corporate governance a scheme can be entrepreneurial in nature that will enable youth to be self-reliant, provide food for the teeming population and also make the environment habitable. The issue of sustainable development is about grassroots and the political will. No countryand organization can truly claim to be serious about that thermometer of governance until it tackles it from the bottom. While the corporate environment continues to change, it is clear that sustainable bench marks may be needed against which the impact of such change might be evaluated in forming expectation about the likely results. The Niger Delta region, with its mammoth wealth in oil resources and a vast, gloomy geography of apparent neglect require the presence of good corporate governance which is impliedly the watch dog and conscience of the shareholders and other interest groups to who will be reported the well-being of the organization. To foster sustainable development, government should provide stable investment rules, regulatory incentives while business to provide innovative cluster with its economic engine. Because they will close down if they fail to innovate successfully.

\section{Recommendations}

a) To achieve sustainable development in the Niger Delta, regulatory agencies should ensure that all stakeholders comply with environmental laws and corporate governance guidelines.

b) Companies in the oil industry should employ modern technology and skilled manpower in their operations to avert operational error and environmental damages.

c) Entrepreneurial skill should be encouraged through development agencies to provide job opportunities. This will reduce militancy in the operational domain of the oil companies.

d) Managers should adopt policies that are innovative and creative to achieve organizational excellence.

\section{References}

Afinotan, L. A., \& Ajakorotu, V. (2009). The Niger Delta Crisis: issues, challenges and prospects. African Journal of political Science and International Relations, 3(5), 191-198.

Dittih. (1998). Technological Transfer problems in Nigeria. The Nigeria Environment and Socio-Economic Development. SIJ publisher.

Eyinla, E. (2006). Nigeria: the travesty of oil and gas wealth in Lagos. The catholic secretariat of Nigeria.

Lini \& Hwang. (2010). Audit quality, corporate Governance and Earnings management: A metal Analysis. International Journal of Auditing, 1457-77.

Micah, I., \& Adebayo. (2012). Corporate social responsibility and compliance with regulation in Nigeria. Research Journal of Finance and Accounting, 3(2).

Natufe. (2009). The problem of sustainable development and corporate social Responsibility: Policy implications for the Niger Delta.

OECD. (2000). Gidelines for multinational Enterprises, Paris.

Oyebode, A. (2009). The imperative of corporate governanace in Nigeria, Nigeria village sqname Oyster (2012) Transforming the Niger Delta. Quaterly Magazine of the Niger Delta Development Commission.

Small \& witherich. (1987). Edward Arnold (2nd ed.). London: 1989.

Uduaghan. (2012). The issue of resource control. The nation newspaper. 